American Journal of Pharmaceutical Education 2020; 84 (8) Article 7805.

\title{
BRIEF
}

\section{A Co-Curricular Activity to Introduce Pharmacy Students to the Concepts of Innovation and Entrepreneurship}

\author{
Amanda Mogul, PharmD, Elizabeth Laughlin, BSPS, Sarah Lynch, PharmD \\ Binghamton University, School of Pharmacy and Pharmaceutical Sciences, Johnson City, New York \\ Submitted August 2, 2019; accepted March 15, 2020; published August 2020.
}

Objective. To develop, implement, and evaluate a co-curricular activity in which second-year Doctor of Pharmacy (PharmD) students developed an idea for a new clinical pharmacy service.

Methods. A brief co-curricular activity based on the television series SharkTank was developed to encourage innovation and entrepreneurship. Second-year pharmacy students worked in assigned teams and were allowed one hour to develop an innovative clinical service to solve a pharmacy-related problem. Students then "pitched" their idea to a panel of four faculty members who served as the "sharks" and graded the teams using a rubric. The rubric which was employed was mapped to the Center for the Advancement of Pharmacy Education (CAPE) Educational Outcomes. A pre- and postactivity survey was administered to students to gather information about changes in their perceptions of innovation and entrepreneurship in pharmacy.

Results. Student groups received higher scores on their ability to present background information and the need for their clinical service and lower scores in areas such as tracking outcomes and predicting challenges. On the post-activity survey, $96.7 \%$ of students agreed that the activity gave them a better understanding of pharmacists' roles in establishing new clinical services, and $86.7 \%$ stated they intend to actively seek out new clinical pharmacy service opportunities in their future career.

Conclusion. Results of the survey demonstrate that students understand the importance of innovation and entrepreneurship in pharmacy practice, and almost all students felt that the activity gave them an even better understanding of the pharmacist's role in clinical service development. This activity can serve as a blueprint for schools of pharmacy looking to incorporate creative and fun methods of exposing PharmD students to innovation and entrepreneurship activities.

Keywords: co-curricular, innovation, entrepreneurship, personal and professional development

\section{INTRODUCTION}

Innovation and entrepreneurship are critical elements needed for pharmacists to continue to expand and improve pharmacy clinical services. Development and implementation of new clinical pharmacy services requires pharmacists to have strong business acumen and creative thinking skills. These skills are especially important as pharmacists strive to advance the profession. Doctor of Pharmacy (PharmD) students who have more exposure to innovation and entrepreneurship will be better stewards of the profession. However, innovation and entrepreneurship skills can be difficult to teach and assess, and their coverage in pharmacy educational

Corresponding Author: Amanda Mogul, Binghamton University, School of Pharmacy and Pharmaceutical Sciences, 96 Corliss Ave., Johnson City, NY 13790. Tel: 607-777-5834. Email: amogul@binghamton.edu programs can easily be minimalized and priority given to other required curricular elements. ${ }^{1}$

The Center for the Advancement of Pharmacy Education (CAPE) 2013 Educational Outcomes guide the required components of pharmacy education. ${ }^{2}$ Domains 3 and 4 of the CAPE Educational Outcomes address "approach to practice and care" and "professionalism." Standard 4.3 specifically covers "Innovation and Entrepreneurship," stating that students should be "engaging in innovative activities by using creative thinking to envision better ways of accomplishing professional goals."

The Accreditation Council for Pharmacy Education (ACPE) Standards 2016 stipulate that co-curricular activities are offered as an adjunct to didactic experiences. ${ }^{3}$ The PharmD co-curriculum provides the unique opportunity for faculty members to develop activities that challenge student creativity and innovation. ${ }^{4}$

Innovation and entrepreneurship topics are traditionally included within the didactic curriculum in the 


\section{American Journal of Pharmaceutical Education 2020; 84 (8) Article 7805.}

context of social and administrative sciences. Several studies have described activities where students apply and practice innovation and entrepreneurship skills in the didactic classroom, but so far there have been no studies published on similar co-curricular activities. ${ }^{5,6}$ There are also few publications regarding co-curricular programs that specifically assess Domains 3 and 4 of the CAPE 2013 Educational Outcomes. ${ }^{7-9}$

The co-curricular activity described below was developed for second-year (P2) pharmacy students at the Binghamton University School of Pharmacy and Pharmaceutical Sciences to address the CAPE Educational Outcomes of innovation and entrepreneurship, which are particularly difficult to assess. The activity was based on the popular television series, Shark Tank (www.abc.com), in which entrepreneurs pitch their ideas for a product or service to a panel of successful entrepreneurs and business executives for feedback. Following the activity, students were surveyed about their current perception of pharmacy innovation. It was the researchers' goal that this activity would inspire students and promote their confidence in establishing new clinical pharmacy services. Our objectives were to develop, implement, and evaluate the activity focusing on students' ability to successfully develop a new clinical pharmacy service and effectively "pitch" their idea, and determine the effect of the activity on students' perceptions of innovation as it applies to their own future practice and pharmacy in general.

\section{METHODS}

This was an optional Shark Tank-style co-curricular activity for P2 pharmacy students in spring 2019. This activity was one of several co-curricular activities offered during the 2018-2019 academic year to fulfill P2 students' requirement for education in innovation and entrepreneurship. All P2 students were invited to participate via a learning management system in a group created to distribute information to students about co-curricular opportunities. This study received investigational review board exemption and informed consent was obtained from all participants.

Students were challenged to create a new clinical pharmacy service for a local hospital aiming to reduce readmissions for one of the following conditions: acute myocardial infarction, chronic obstructive pulmonary disease, heart failure, pneumonia, coronary artery bypass graft surgery, and elective primary total hip arthroplasty and/or total knee arthroplasty. Ten groups of three or four students were formed. Prior to the activity, students were given optional pre-reading materials for background knowledge on hospital readmissions and an example of a clinical pharmacist's intervention aimed at reducing readmission. In addition to the scenario, groups were given questions to guide their development of the service and business plan. The 10 groups had one hour to develop a plan. Each group then presented a five-minute verbal pitch to a panel of four faculty members (which included two of the project investigators) who served as the judges or "sharks."

Prior to the activity, researchers developed a rubric to evaluate each proposal and assess performance in personal and professional domain categories (Appendix 1). The rubric included sections for each business plan element. The rubric categories mirrored the guided questions. Scoring levels were defined as above average, average, basic, or below expectations. These levels were assigned numbers which were used to calculate overall team scores and determine winners (4-3-2-1). Each row of the rubric was mapped to CAPE 2013 Educational Outcomes. Faculty members independently graded each presentation using this rubric.

An invitation to voluntarily and anonymously complete pre- and post-activity surveys on Qualtrics (Qualtircs Survey Software, Provo, UT) was emailed to the students. The pre-survey invitation was emailed one week prior to the activity and the post-survey was administered immediately following the event. The survey instruments consisted of opinion-based questions concerning innovation and entrepreneurship as it relates to pharmacy services. Survey responses were based on a five-point Likert scale (strongly agree, agree, neutral, disagree, and strongly disagree). There were nine identical questions on the pre- and post-survey instruments, and three additional questions on the postsurvey instrument. Students created an anonymous code using three unique identifiers, and students' codes were used to match pre- and post-activity survey results.

To determine each group's final score, researchers calculated the percent of scores awarded for each category and reported each group's results in aggregate. Researchers performed a paired $t$ test for dependent variables to determine whether there were significant changes between students' pre- and post-survey responses. Survey results were dichotomized, with responses of strongly agree and agree grouped in the "agree" category and responses of neutral, disagree, and strongly disagree grouped into the "disagree" category. Only the survey instruments of those students who accurately completed the unique coding to match their pre-and post-survey results were included in the statistical analysis.

\section{RESULTS}

Of 58 students in the P2 cohort, 38 students chose to participate for a response rate of $73 \%$. The majority of rubric scores were in the above average and average categories (Table 1). Over $85 \%$ of scores awarded were 


\section{American Journal of Pharmaceutical Education 2020; 84 (8) Article 7805.}

Table 1. Second-Year Doctor of Pharmacy Students Rubric Scores for an Innovation and Entrepreneurship Co-Curricular Activity: Aggregate Score Distribution Across all Faculty and Student Groups $(\mathrm{N}=40)$

\begin{tabular}{|c|c|c|c|c|}
\hline \multirow{2}{*}{$\begin{array}{l}\text { Rubric Criteria (CAPE Educational } \\
\text { Outcome) }\end{array}$} & \multicolumn{4}{|c|}{ Faculty Score, No. (\%) } \\
\hline & Above Average & Average & Basic & Below Expectations \\
\hline $\begin{array}{l}\text { Proposal: Identification and description of the } \\
\text { service and primary goal(s) }(3.1 .2)(\mathrm{n}=40)\end{array}$ & $14(35)$ & $18(45)$ & $7(17.5)$ & $1(2.5)$ \\
\hline $\begin{array}{l}\text { Proposal: Appropriateness for pharmacy and } \\
\text { overall feasibility }(4.3 .2)\end{array}$ & $17(42.5)$ & $14(35)$ & $8(20)$ & $1(2.5)$ \\
\hline $\begin{array}{l}\text { Proposal: Level of innovation and realism } \\
\quad(4.3 .3,4.3 .5)^{\mathrm{a}}\end{array}$ & $9(23.7)$ & $24(63.2)$ & $4(10.5)$ & $1(2.6)$ \\
\hline $\begin{array}{l}\text { Background: Why is the service necessary; how } \\
\text { will the health system benefit? }(4.4 .5)^{\mathrm{b}}\end{array}$ & $23(59.0)$ & $14(36.0)$ & $1(2.5)$ & $1(2.5)$ \\
\hline $\begin{array}{l}\text { Role delineation: Define specific roles of the } \\
\text { RPH, tech, student. How will you partner } \\
\text { with other non-pharmacy members of the } \\
\text { healthcare team? (3.4.2) }\end{array}$ & $15(37.5)$ & $16(40)$ & $8(20)$ & $1(2.5)$ \\
\hline $\begin{array}{l}\text { Financial analysis: How will your budget be } \\
\text { allotted? (2.2.4) }\end{array}$ & $16(40)$ & $18(45)$ & $5(12.5)$ & $1(2.5)$ \\
\hline $\begin{array}{l}\text { Outcome tracking: Identify } 3-5 \text { specific } \\
\text { outcomes you will track to determine the } \\
\text { impact of your clinical service. }(3.1 .5)\end{array}$ & $6(15)$ & $15(37.5)$ & $11(27.5)$ & $8(20)$ \\
\hline $\begin{array}{l}\text { Challenges: What challenges do you perceive } \\
\text { with implementing this plan? How do you } \\
\text { plan to overcome these challenges? }(3.1 .4 \text {, } \\
4.3 .1)\end{array}$ & $3(7.5)$ & $20(50)$ & $6(15)$ & $11(27.5)$ \\
\hline $\begin{array}{l}\text { Presentation: Presentation skills, appropriate } \\
\text { time, ability to answer questions (3.6.5) } \\
(\mathrm{n}=40)\end{array}$ & $19(47.5)$ & $20(50)$ & $1(2.5)$ & $0(0)$ \\
\hline
\end{tabular}

Abbreviations: $\mathrm{CAPE}=$ Center for the Advancement of Pharmacy Education

${ }^{a}$ Two of the 40 responses were missing for this item

${ }^{\mathrm{b}}$ One of the 40 responses was missing for this item

"above average" or "average" in the following categories: "Proposal: Level of Innovation and Realism," "Background," "Financial Analysis," and "Presentation Skills." Scores were lower for "Outcome tracking" and "Challenges," with $52.5 \%$ and $57.5 \%$ of scores "above average" or "average," respectively.

All 38 student participants (100\%) completed both the pre- and post-activity surveys. Thirty surveys were included in the matched analysis. Overall, pre- and postsurvey results were similar. In the matched cohort, there were no significant differences in any of the survey question responses (Table 2). There was a small but insignificant increase in the number of students who agreed with certain questions after completing the activity compared to before. These included, "Pharmacists are responsible for IDENTIFYING needs in a health care system" (80\% to 93.3\%) and "Pharmacists have the ability to create career growth and opportunities for themselves within health care systems" (86.7\% to $96.7 \%)$.

The three additional post-survey questions were intended to solicit feedback on the activity and provoke self-reflection among the students. Overall, these statements reflected a high rate of agreement. Of participating students, $96.7 \%$ agreed that the activity gave them a better understanding of pharmacists' roles in establishing new clinical services. Furthermore, $86.7 \%$ stated that they intend to actively seek out clinical pharmacy service opportunities in their future career.

\section{DISCUSSION}

This activity provided students a unique opportunity to practice skills that are challenging to assess within the traditional classroom setting. There were clear trends in the distribution of rubric scores across groups (Table 1). Students performed better on more basic areas of the proposal, which was expected. The highest performing category was the background (CAPE Educational Outcome 4.4.5), in which students were asked to explain: "Why is the service necessary? How will the health system benefit?" In this category, 95\% of awarded scores were "above average" or "average." Lower scores were awarded for more challenging areas of tracking outcomes 


\section{American Journal of Pharmaceutical Education 2020; 84 (8) Article 7805.}

Table 2. Second-Year Doctor of Pharmacy Students Survey Responses Regarding Participation in a Co-curricular Activity to Encourage Innovation and Entrepreneurship $(\mathrm{N}=30)$

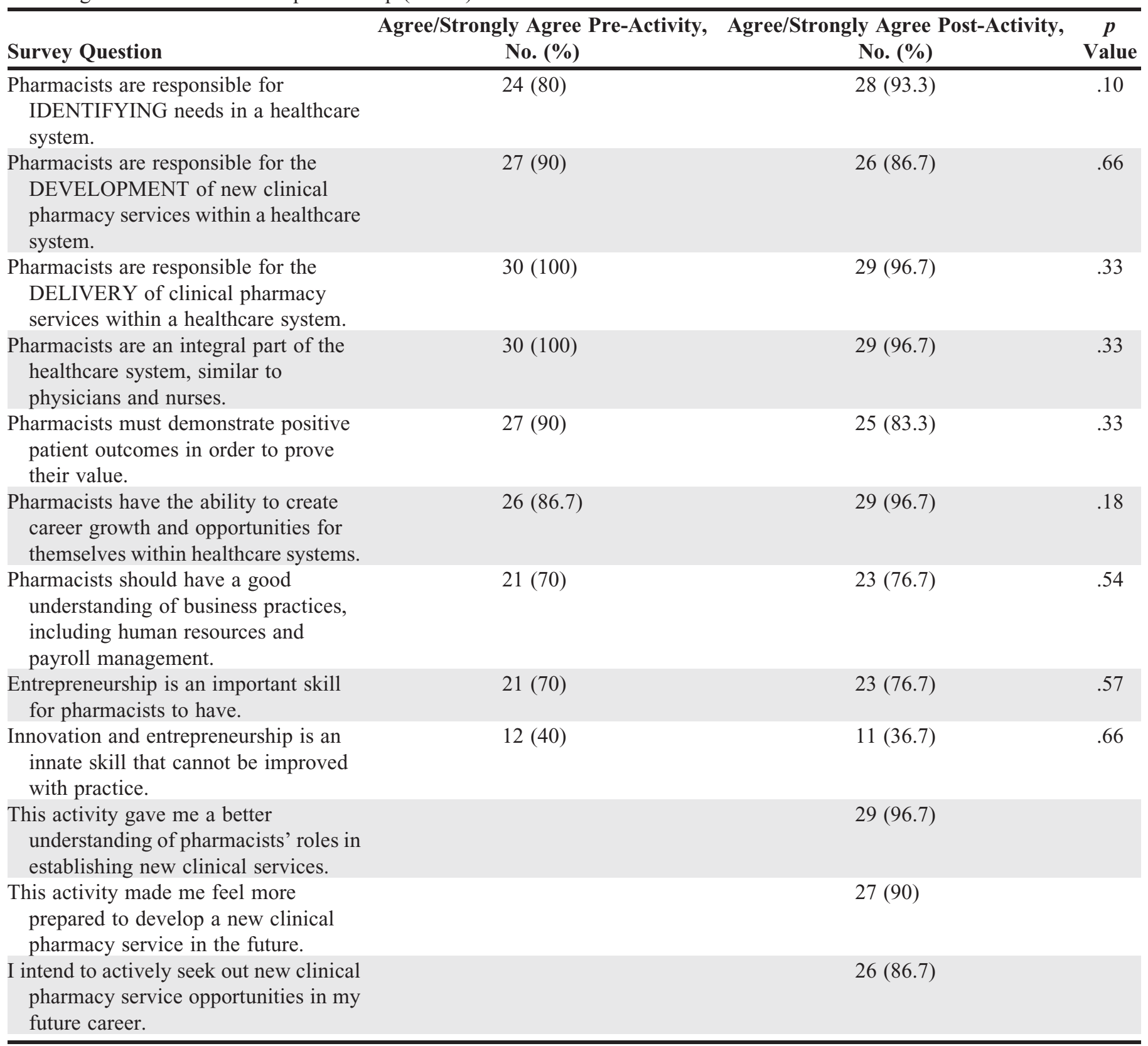

${ }^{a}$ Individual pre- and post-survey results were matched using an anonymous code of unique identifiers. Only the survey instruments of those students who accurately completed the unique coding to match their pre-and post-survey results were included in the statistical analysis

(CAPE Educational Outcome 3.1.5) and predicting challenges (CAPE Educational Outcomes 3.1.4, 4.3.1). This is not surprising, as these areas are a higher-level skill set and require a more advanced understanding of the task. These skills fall within the areas of "personal and professional development" that this activity was aiming to assess. These results can be used to develop activities that enhance these skills in pharmacy students before graduation. Lastly, the students performed extremely well in the presentation category, where they were judged on their presentation skills and ability to answer questions ( $97.5 \%$ of scores above average or average).

The rubric was intended to add a level of objectivity to the score ranking. Students did not see the rubric prior to their presentation; however, they were given guided questions which mirrored the rubric categories. While groups were presenting, faculty members offered little commentary and asked few questions, and allowed each team of students to organize their presentation as they deemed best within the time limit. Although rubric scores 


\section{American Journal of Pharmaceutical Education 2020; 84 (8) Article 7805.}

were subjective, the researchers sought to standardize scoring by having the same four faculty members grade each group. Each faculty member likely used their own personal scale for what was determined to be "above average," "average," and so forth. However, we assumed that each faculty member used the same scale for assessing each group, which allowed the total scores for each group to be compared to determine a winning group.

Survey results revealed insignificant changes in student perception before and after the activity, which could be attributed to a few factors. First, this activity was voluntary, therefore it may be assumed that students who self-selected to participate already understood the importance of innovation and entrepreneurship. Although all students are required to complete an innovation and entrepreneurship co-curricular activity during their P2 year, there are several options. While students were not aware of the activity details when completing the preactivity survey, they knew that this activity satisfied a certain co-curricular category, which may have biased their responses. Additionally, the pre-activity reading assignment likely impacted the opinions expressed on the pre-survey. Finally, the small sample size may have limited the ability to detect significant changes.

Even with the lack of significant change, we found it encouraging that students agreed pharmacists should have innovation and entrepreneurship roles and mindsets. Several commentaries have suggested the pharmacy profession has been held back because the "typical" pharmacist lacks personality traits that lend themselves to innovative thinking and action, such as risk-taking and competitiveness. ${ }^{10,11}$ The same traits that tend to be associated with pharmacists (eg, detail oriented, harmonyseeking, responsible) may deter individuals from developing their own clinical practice because of the element of risk involved. Through the co-curriculum, it is possible to increase students' exposure to "riskier" activities in a safe classroom setting. More exposure will increase familiarity and comfort with new service development, and may encourage students to pursue these opportunities after school. Co-curricular activities give students the opportunity to apply creative thinking outside of the realm of grades and competencies, a limitation to creative thinking identified in previous pharmacy entrepreneurship activities and courses. ${ }^{5}$

At Binghamton University, students receive no formal exposure to the principles of clinical service development until the third professional year. However, pharmacy jurisprudence is instructed during the first professional year so students have been introduced to some vocabulary and concepts related to new clinical service development (eg, collaborative practice agreements). Some students anecdotally shared descriptions of their exposure to clinical service development at their internship or IPPE sites. In general, however, the researchers were impressed with students' level of interest and apparent understanding of concepts considering their lack of formal exposure.

Factors in this study such as participation, selfselection, pre-reading materials, and use of a non-validated survey instrument and rubric may have created bias in results. Although this study was performed in a small cohort of students and did not demonstrate statistical significance, this activity was simple to prepare, realistic to clinical practice, and enjoyed by students. This study contributes to the paucity of data describing the teaching of innovation and entrepreneurship elements, especially within the cocurriculum. This study can serve as a blueprint for schools of pharmacy looking to incorporate creative and fun methods of teaching and assessing these topics.

\section{CONCLUSION}

Co-curricular activities provide excellent opportunities to build upon the core curriculum to enhance learning. Areas of innovation and entrepreneurship are required elements within the CAPE standards, but these can be challenging topics to teach and assess. With the growing number of PharmD graduates seeking jobs, it is increasingly important that students graduate with the ability to "think outside the box" if they plan to create more clinical pharmacist positions. Co-curricular activities that challenge students to have this mindset can provide important exposure and practice for students. The more students are encouraged to innovate, the more comfortable they may be with proposing new clinical services as practitioners.

\section{ACKNOWLEDGMENTS}

The authors thank Emily E. Leppien, PharmD, BCPS and Khalid Srour, PharmD for their assistance in facilitating and scoring this co-curricular activity.

\section{REFERENCES}

1. Brazeau G. Entrepreneurial spirit in pharmacy. Am J Pharm Educ. 2013;77(5):Article 88. https://www.ajpe.org/doi/abs/10.5688/ ajpe77588. Accessed July 20, 2020.

2. Medina MS, Plaza CM, Stowe CD, et al. Center for the Advancement of Pharmacy Education 2013 Educational Outcomes. Am J Pharm Educ. 2013;77(8):Article 162. https://www.ajpe.org/ content/77/8/162. Accessed July 20, 2020.

3. Accreditation Council for Pharmacy Education. Accreditation Standards and Key Elements for the Professional Program in Pharmacy Leading to the Doctor of Pharmacy Degree. 2015. https:// www.acpe-accredit.org/pdf/Standards2016FINAL.pdf. Accessed July 20, 2020. 


\section{American Journal of Pharmaceutical Education 2020; 84 (8) Article 7805.}

4. Patel UJ, Mediwala KN, Smith KM, Taylor S, Romanelli F. Carpe diem! seizing the rise of co-curricular experiences. Am J Pharm

Educ. 2017;81(8):Article 6702. https://www.ajpe.org/content/81/8/ 6702. Accessed July 20, 2020

5. Laverty G, Hanna LA, Haughey S, Hughes C. Developing entrepreneurial skills in pharmacy students. Am J Pharm Educ. 2015;79(7):Article 106. https://www.ajpe.org/content/79/7/106. Accessed July 20, 2020.

6. Hermansen-Kobulnicky CJ, Moss CL. Pharmacy student entrepreneurial orientation: a measure to identify potential pharmacist entrepreneurs. Am J Pharm Educ. 2004;68(5):Article 113. 7. Ramia E, Salameh P, Btaiche IF, Saad AH. Mapping and assessment of personal and professional development skills in a pharmacy curriculum. BMC Med Educ. 2016;16:Article 19. https:// bmcmededuc.biomedcentral.com/articles/10.1186/s12909-0160533-4. Accessed July 20, 2020.
8. Vos SS, Sabus A, Seyfer J, Umlah L, Gross-Advani C, ThompsonOster J. Using continuing professional development to create meaningful co-curricular learning opportunities for all student pharmacists. Am J Pharm Educ. 2018;82(4):Article 6270. https:// www.ajpe.org/content/82/4/6270. Accessed July 20, 2020.

9. Hoffman J, Chung E, Hess K, Law AV, Samson B, Scott JD. Overview of a co-curricular professional development program in a college of pharmacy. Curr Pharm Teach Learn. 2017;9(3):398-404. https://doi.org/10.1016/j.cptl.2017.01.010. Accessed July 20, 2020.

10. Nimmo CM, Holland RW. Transitions in pharmacy practice, part 4: can a leopard change its spots? Am J Health Syst Pharm. 1999;56(23):2458-2462. https://doi.org/10.1093/ajhp/56.23.2458. Accessed July 20, 2020.

11. Rosenthal M, Austin Z, Tsuyuki RT. Are pharmacists the ultimate barrier to pharmacy practice change? Can Pharm J. 2010;143(1):37-42. https://doi.org/10.3821/1913-701X-143.1.37. Accessed July 20, 2020. 


\section{American Journal of Pharmaceutical Education 2020; 84 (8) Article 7805.}

Appendix 1. Rubric Used by Faculty Members to Assess Second-Year Doctor of Pharmacy Students' Presentations in a CoCurricular Activity to Encourage Innovation and Entrepreneurship ${ }^{2}$

\begin{tabular}{|c|c|c|c|c|}
\hline $\begin{array}{l}\text { Category (CAPE } \\
\text { outcomes) }\end{array}$ & Above Average & Expected & Basic & Below Expectations \\
\hline $\begin{array}{l}\text { Proposal: Identification } \\
\text { and description of the } \\
\text { service and primary } \\
\text { goal(s) (3.1.2) }\end{array}$ & $\begin{array}{l}\text { Service clearly } \\
\text { identified; Concise } \\
\text { description; Plan is } \\
\text { well developed; Goals } \\
\text { are specific and } \\
\text { attainable }\end{array}$ & $\begin{array}{l}\text { Service identified with } \\
\text { some omissions/ } \\
\text { confusion; Good } \\
\text { description of plan; } \\
\text { Plan is mostly well } \\
\text { developed with some } \\
\text { missing pieces; Goals } \\
\text { are somewhat specific } \\
\text { and mostly attainable }\end{array}$ & $\begin{array}{l}\text { Service is poorly } \\
\text { identified or } \\
\text { described; Plan is } \\
\text { poorly developed or } \\
\text { incomplete; Some } \\
\text { goals may be } \\
\text { unattainable or non- } \\
\text { specific }\end{array}$ & $\begin{array}{l}\text { Service is unclear; Poor } \\
\text { description of service; } \\
\text { Lack of a developed } \\
\text { plan; Goals are non- } \\
\text { specific or } \\
\text { unattainable }\end{array}$ \\
\hline $\begin{array}{l}\text { Proposal: } \\
\text { Appropriateness for } \\
\text { pharmacy and overall } \\
\text { feasibility }(4.3 .2)\end{array}$ & $\begin{array}{l}\text { Service is feasible and } \\
\text { appropriate for RPH; } \\
\text { Relevant to pharmacy } \\
\text { practice }\end{array}$ & $\begin{array}{l}\text { Service is mostly } \\
\text { feasible, and } \\
\text { appropriate for RPH; } \\
\text { Relevant to pharmacy } \\
\text { practice }\end{array}$ & $\begin{array}{l}\text { Poor feasibility and } \\
\text { appropriateness for } \\
\text { RPH; Slight relevance } \\
\text { to pharmacy practice }\end{array}$ & $\begin{array}{l}\text { Service is not feasible; } \\
\text { Not relevant to } \\
\text { pharmacy practice }\end{array}$ \\
\hline $\begin{array}{l}\text { Background: Why is this } \\
\text { service necessary; } \\
\text { how will the health } \\
\text { system benefit? } \\
(4.4 .5)\end{array}$ & $\begin{array}{l}\text { Able to provide } \\
\text { justification for } \\
\text { service }\end{array}$ & $\begin{array}{l}\text { Provides justification for } \\
\text { service with some } \\
\text { confusion }\end{array}$ & $\begin{array}{l}\text { Provides little } \\
\text { justification or } \\
\text { benefits of program } \\
\text { are unclear }\end{array}$ & $\begin{array}{l}\text { Unable to provide } \\
\text { justification for } \\
\text { service }\end{array}$ \\
\hline $\begin{array}{l}\text { Role Delineation: Define } \\
\text { specific roles of the } \\
\text { RPH, tech, student. } \\
\text { How will you partner } \\
\text { with other non- } \\
\text { pharmacy members of } \\
\text { the healthcare team? } \\
\text { (3.4.2) }\end{array}$ & $\begin{array}{l}\text { Appropriate role } \\
\text { delineation; Inclusion } \\
\text { of all roles (pharm and } \\
\text { non-pharm); } \\
\text { Appropriate scope of } \\
\text { practice }\end{array}$ & $\begin{array}{l}\text { Role delineation mostly } \\
\text { appropriate; Inclusion } \\
\text { of most roles with } \\
\text { some omissions; } \\
\text { Appropriate scope of } \\
\text { practice }\end{array}$ & $\begin{array}{l}\text { Role delineation was } \\
\text { somewhat } \\
\text { inappropriate or was } \\
\text { not completely } \\
\text { addressed; Mostly/ } \\
\text { somewhat appropriate } \\
\text { scope of practice }\end{array}$ & $\begin{array}{l}\text { Role delineation } \\
\text { inappropriate or not } \\
\text { addressed; Exclusion } \\
\text { of pertinent roles; } \\
\text { Inappropriate scope of } \\
\text { practice }\end{array}$ \\
\hline $\begin{array}{l}\text { Outcome Tracking: } \\
\text { Identify } 3-5 \text { specific } \\
\text { outcomes you will } \\
\text { track to determine the } \\
\text { impact of your } \\
\text { clinical service. } \\
(3.1 .5)\end{array}$ & $\begin{array}{l}\text { Outcomes are specific } \\
\text { and attainable; } \\
\text { Outcomes relate } \\
\text { directly back to task } \\
\text { of reducing } \\
\text { readmissions }\end{array}$ & $\begin{array}{l}\text { Outcomes are mostly } \\
\text { attainable and } \\
\text { specific, with few } \\
\text { exceptions; Outcomes } \\
\text { mostly align with task } \\
\text { of reducing } \\
\text { readmissions, with } \\
\text { few exceptions }\end{array}$ & $\begin{array}{l}\text { Outcomes are addressed } \\
\text { but are very general or } \\
\text { unattainable; } \\
\text { Outcomes poorly } \\
\text { align with task of } \\
\text { reducing readmissions }\end{array}$ & $\begin{array}{l}\text { Outcomes are missing or } \\
\text { inappropriate for } \\
\text { proposal; Outcomes } \\
\text { do not align with task } \\
\text { of reducing } \\
\text { readmissions }\end{array}$ \\
\hline
\end{tabular}


American Journal of Pharmaceutical Education 2020; 84 (8) Article 7805.

(Continued)

\begin{tabular}{|c|c|c|c|c|}
\hline $\begin{array}{l}\text { Category (CAPE } \\
\text { outcomes) }\end{array}$ & Above Average & Expected & Basic & Below Expectations \\
\hline $\begin{array}{l}\text { Challenges: What } \\
\text { challenges do you } \\
\text { perceive with } \\
\text { implementing this } \\
\text { plan? How do you } \\
\text { plan to overcome } \\
\text { these challenges? } \\
(3.1 .4,4.3 .1)\end{array}$ & $\begin{array}{l}\text { Identification of specific } \\
\text { and realistic } \\
\text { challenges; } \\
\text { Appropriate plan for } \\
\text { overcoming challenge }\end{array}$ & $\begin{array}{l}\text { Challenges are mostly } \\
\text { specific/realistic, with } \\
\text { few exceptions; Plan } \\
\text { for overcoming } \\
\text { challenges is } \\
\text { somewhat appropriate }\end{array}$ & $\begin{array}{l}\text { Poor perception of } \\
\text { realistic challenges, or } \\
\text { challenges are non- } \\
\text { specific; Poor plan for } \\
\text { overcoming } \\
\text { challenges }\end{array}$ & $\begin{array}{l}\text { Challenges are missing } \\
\text { or inappropriate; Plan } \\
\text { for overcoming } \\
\text { challenges } \\
\text { inappropriate or not } \\
\text { addressed }\end{array}$ \\
\hline $\begin{array}{l}\text { Presentation: } \\
\text { Presentation skills, } \\
\text { appropriate time, } \\
\text { ability to answer } \\
\text { questions. (3.6.5) }\end{array}$ & $\begin{array}{l}\text { Speaks with confidence, } \\
\text { appropriate speed and } \\
\text { volume, makes eye } \\
\text { contact; Pitch given in } \\
\text { time allotted; } \\
\text { Answers questions } \\
\text { with confidence and } \\
\text { accuracy }\end{array}$ & $\begin{array}{l}\text { Adequate speed and } \\
\text { volume, eye contact } \\
\text { made during most of } \\
\text { presentation; Pitch } \\
\text { given in time allotted; } \\
\text { Answers questions } \\
\text { adequately }\end{array}$ & $\begin{array}{l}\text { Speed or volume } \\
\text { inappropriate; poor } \\
\text { eye contact or few } \\
\text { distractions during } \\
\text { pitch; Pitch exceeded } \\
\text { allotted time; Some } \\
\text { difficulty answering } \\
\text { questions }\end{array}$ & $\begin{array}{l}\text { Poor dictation, speed or } \\
\text { volume inappropriate; } \\
\text { several distractions; } \\
\text { Pitch exceeded } \\
\text { allotted time; Unable } \\
\text { to answer questions }\end{array}$ \\
\hline
\end{tabular}

$\mathrm{CAPE}=$ Center for the Advancement of Pharmacy Education 